\title{
28 Research Square \\ A Systematic Review on Guidelines and Recommendations for Tracheostomy during Covid-19 Pandemic
}

\section{Dr. Rahulkumar Shah ( $\square$ rahulshah.1010october@gmail.com )}

Pramukhswami medical college

\section{Dr. Priyadarshini G}

Pramukhswami medical college

\section{Dr. Monil Parsana}

Pandit Dindayal Upadhyay medical college

\section{Systematic Review}

Keywords: COVID-19, Tracheostomy, Personal Protetcive Equipments

Posted Date: October 6th, 2020

DOI: https://doi.org/10.21203/rs.3.rs-85820/v1

License: (9) (1) This work is licensed under a Creative Commons Attribution 4.0 International License. Read Full License

Version of Record: A version of this preprint was published at Indian Journal of Otolaryngology and Head \& Neck Surgery on April 29th, 2021. See the published version at https://doi.org/10.1007/s12070-021-02517-9. 


\section{Abstract}

Aim: Global health care is experiencing an unprecedented surge in the number of critically ill patients who require mechanical ventilation due to the COVID-19 pandemic. The requirement for relatively long periods of ventilation in those who survive means that many are considered for tracheostomy to free patients from ventilatory support and maximise scarce resources. COVID-19 provides unique challenges for tracheostomy care: health-care workers need to safely undertake tracheostomy procedures and manage patients afterwards, minimising risks of nosocomial transmission and compromises in the quality of care. Conflicting recommendations exist about the timing and performance of tracheostomy and the subsequent management of patients. This is due to a number of factors including prognosis, optimal healthcare resource utilisation, and safety of healthcare workers when performing such a high-risk aerosol-generating procedure.

Methods: MEDLINE (accessed from PubMed) from 6 august 2019 to 7 august 2020 were systematically searched using: "COVID 19" OR “CORONAVIRUS” OR “SARS COV-2" AND "TRACHEOSTOMY” with filters as '2020' year of study, English language, full article available on 7/08/2020 at $11.30 \mathrm{Am}$.

Results: Total of 56 articles were obtained on search and the final 15 articles extracted based on our selection criteria were reviewed. A synthesis of the current international literature and reported experience is presented with respect to timing of tracheostomy, ideal place for tracheostomy, staff safety, procedure modification and post tracheostomy care thus leading to a pragmatic recommendation that tracheostomy is not performed until at least 14 days after endotracheal intubation in COVID-19 patients and if indicated should be done in negative pressure isolated ICU room with full PPE protection with some modification during procedure.

Conclusion: In selected COVID-19 patients, there is a role for tracheostomy to aid in weaning and optimise healthcare resource utilisation. Tracheostomy can be performed safely with careful modifications to technique and appropriate enhanced personal protective equipment.

\section{Introduction}

The coronavirus disease (covid19) pandemic (caused by the SARS-CoV-2 virus) is the greatest healthcare challenge in a generation. Clinicians are modifying the way they approach day-to-day procedures. Safety and reduction of transmission risk is paramount. Surgical tracheostomies in COVID 19 patients are aerosol generating procedures linked with a significant risk of viral contamination. The recent outbreak of SARS-CoV-2 has reached worldwide proportions since it began in late 2019 [1]. Due to the high virulence via aerosol transmissions, to date COVID-19 has infected more than 30.6 million COVID-19 cases and 950000 deaths[ weekly report WHO on 20 September [2]. Tracheostomy is a common procedure in critically ill patients who require an extended period of time on mechanical ventilation. Use of tracheostomy can facilitate weaning from ventilation and potentially increase the availability of intensive care unit (ICU) beds. When the COVID-19 pandemic spread to Italy and Spain, ICUs had a massive influx of patients who were critically ill, many of whom became candidates for tracheostomy. However, tracheostomy is an aerosol generating procedure, so health-care workers are at risk of infection during insertion and subsequent care, even when appropriate personal protective equipment (PPE) is used. COVID-19 provides unique challenges for tracheostomy care: health-care workers need to safely undertake tracheostomy procedures and manage patients afterwards, minimising risks of nosocomial transmission and compromises in the quality of care. Conflicting recommendations exist about the timing, ideal place, performance of tracheostomy and the subsequent management of patients. 


\section{Methodology}

The report of this systematic review was made according to the recommendations of the Preferred Reporting Items for Systematic Reviews and Meta-Analyses (PRISMA) statement (Fig. 1). The review protocol was not previously registered. MEDLINE (accessed from PubMed) from 6 august 2019 to 7 august 2020 were systematically searched for related published articles. In electronic databases, the following search strategy was implemented and these key words (in the title/abstract) were used: "COVID 19" OR "CORONAVIRUS" OR "SARS COV-2" AND "TRACHEOSTOMY". Articles written in English and available full text were all included in this search. All authors participated through each phase of the review independently (screening, eligibility, and inclusion). They independently screened the titles and abstracts yielded by the search against the inclusion criteria. They resolved any disagreement through discussions. Neither of the authors were blind to the journal titles or to the study authors or institutions. The following data were extracted from the included studies: study authors, study designs, main results. The methodological quality of the included studies was assessed by the authors. Aim of this systemic review is to provide a contemporaneous review of emerging data on COVID-19 with direct relevance to the planning, conduct, and subsequent management of tracheostomy during the pandemic. We included only human studies and articles with clearly defined clinical outcome. The exclusion criteria included animal studies and review articles. The search was performed at specified date and time on 7/08/2020 at $11.30 \mathrm{Am}$.

\section{Results}

Total of 56 full article studies were obtained on PubMed database search, out of which 41 studies were excluded after checking the relevance of title, not relevant content, review articles, head neck oncology related tracheostomy. Search was done strictly adhering to the PRISMA guidelines, as depicted in figure 1 . We reviewed the final 15 articles based on our selection criteria to extract the following information from each: first author, date of publication. study design, main results data related to tracheostomy guidelines. The extracted data is jotted in Table 1. 


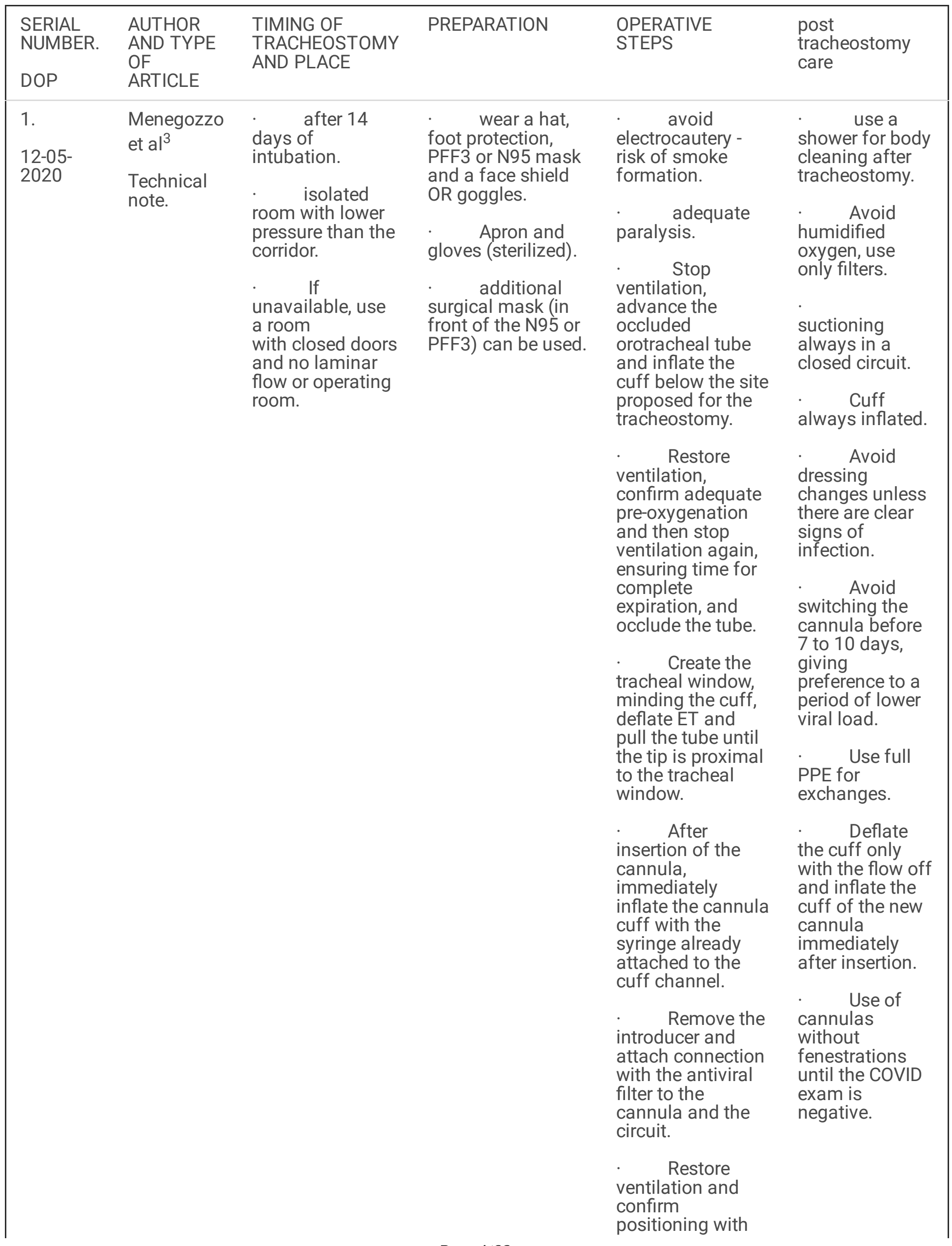




\begin{tabular}{|c|c|c|c|c|c|}
\hline & & & & $\begin{array}{l}\text { capnography } \\
\text { (avoid using the } \\
\text { stethoscope). }\end{array}$ & \\
\hline $\begin{array}{l}2 . \\
\text { 04-Apr-20 }\end{array}$ & $\begin{array}{l}\text { Jacob et } \\
\text { al }^{4} \\
\text { letter TO } \\
\text { EDITOR }\end{array}$ & $\begin{array}{l}\quad \text { Negative } \\
\text { pressure theatre } \\
\text { or isolated room } \\
\text { a If not } \\
\text { available } \\
\text { consider a } \\
\text { normal theatre } \\
\text { with closed doors } \\
\text { during the } \\
\text { procedure. } \\
\text { Consider } \\
\text { turning off } \\
\text { laminar flow [ if } \\
\text { present]. }\end{array}$ & $\begin{array}{l}\cdot \quad \text { surgeons } \\
\text { must wear full } \\
\text { PPE. } \\
\text { · Consider } \\
\text { additional } \\
\text { protection - } \\
\text { powered air } \\
\text { purifying } \\
\text { respirator-PAPR. }\end{array}$ & 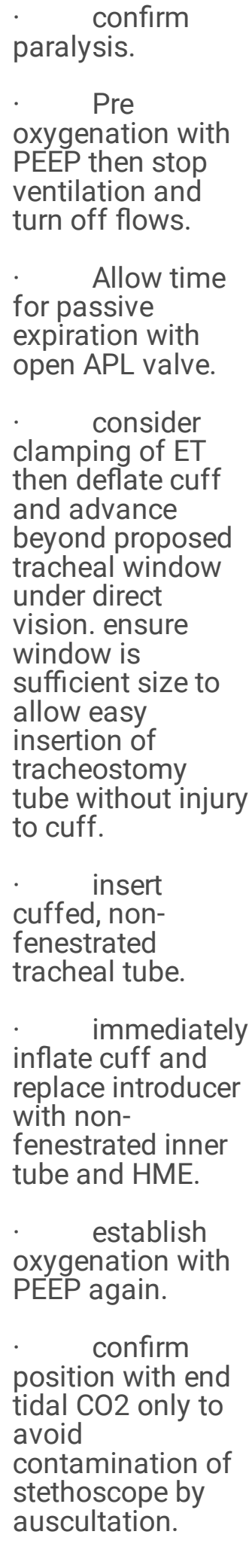 & 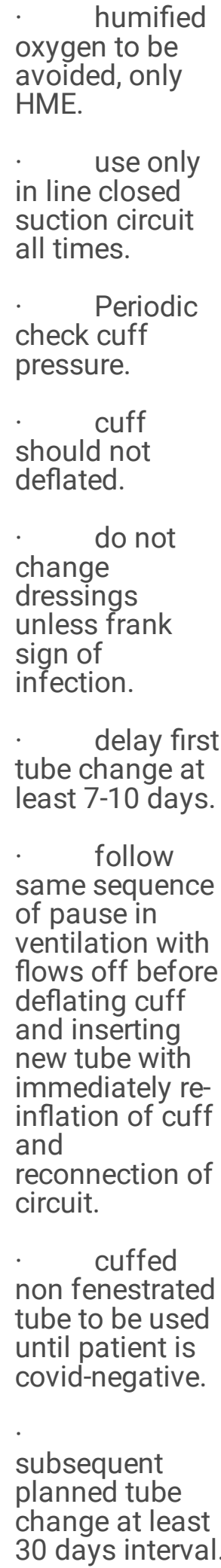 \\
\hline 3. & $\begin{array}{l}\text { Souza } \\
\text { Lima et al } \\
\text { technical } \\
\text { note }\end{array}$ & & $\begin{array}{l}\text { Reduce team } \\
\text { members to just } \\
\text { the essential } \\
\text { required } \\
\text { professionals. }\end{array}$ & $\begin{array}{l}\quad \text { initial } \\
\text { advance of the } \\
\text { endotracheal tube } \\
\text { before the TCT } \\
\text { window is } \\
\text { performed to }\end{array}$ & $\begin{array}{l}\text {. Avoid } \\
\text { changing the } \\
\text { tracheostome } \\
\text { until the patient } \\
\text { has a COVID-19 } \\
\text { negative. }\end{array}$ \\
\hline
\end{tabular}

Page 5/23 


$\quad$ Use the FFP3
/ N95 mask,
integrated visor/
full face shield /
disposable sterile
gowns resistant to
liquids / fluids
(waterproof).
$\quad$ Consider
using "two gloves".
$\quad$ Use a
conventional
tracheostome,
avoiding the
fenestrated
models.

reduce aerosol

elimination;

- If possible, stop

ventilation while

the tracheal

incision is being

performed, and

check that the

cuff is already

inflated before

restarting

ventilation;

- Ventilation

should be stopped

before the

insertion of the

tracheostome, and

perform a fast

and accurate

placement of the

tracheostome with

immediate

inflation of the

cuff;

- Confirm the

adequate

placement,

preferentially, with

capnography, if

available.

- An HME type

filter (Heat and

moisture

exchanger) must

be placed on the

tracheostome to

reduce the

exposure of the

virus, in case of

disconnection.

$\begin{array}{lll}4 . & \begin{array}{l}\text { Bottia et } \\ \mathrm{al}^{6}\end{array} & \begin{array}{l}\text { ICU room } \\ \text { with negative } \\ \text { pressure. }\end{array} \\ & \text { case report } & \end{array}$

sterile gown,
cap, shoe covers,
double gloves, N95
mask, goggles and
face mask.

Paralyse the
patient.
adequate
preoxygenation,

electrocautery.

Stop

mechanical

ventilation before

tracheotomy.

cuff of the

endotracheal tube.

Push the

tube forward 3

$\mathrm{cm}$.
- Only closed-circuit suction should be used. 


\section{Perform}

tracheotomy with

cold knife.

or wound

No tracheal

suctioning of

blood or

secretions should

be attempted if

not needed, to

avoid aerosol

generation.

- Pull the

endotracheal tube

just above the

tracheal incision

under direct

vision.

- Insert the

tracheal cannula,

correctly inflate.

- $\quad$ Give

ventilation again.

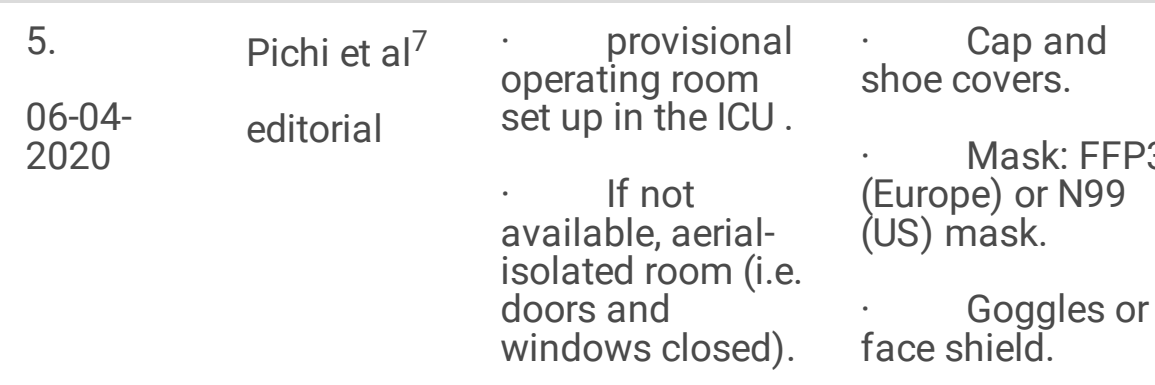

$\quad$ use of
double gown is
preferable.
$\quad$ use of
double nitrile
gloves is
suggested.

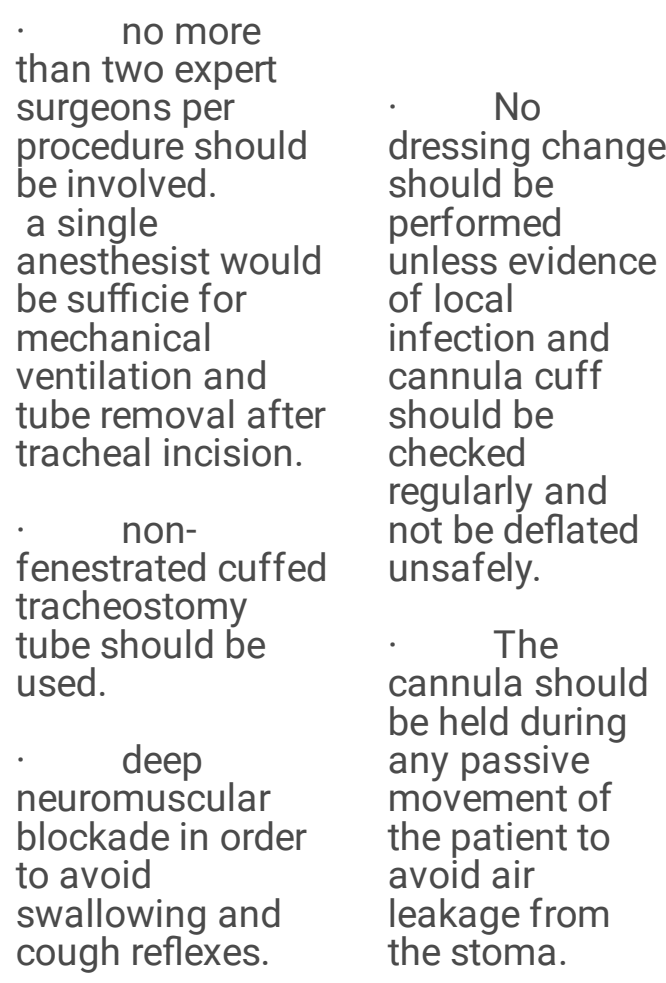

- Once the anterior wall of the trachea is exposed, the anesthetist:

- reduces the oxygen-

percentage of the inflated air to $21 \%$; - pushes the tube as caudally as 
possible, so as to avoid cuff breach, - hyper-inflates

the tube cuff to

ensure lower

airway isolation.

ventilation

is stopped entirely, the tracheal tube

is lifted, without

extubating the

patient, until its

bottom side

passes the

tracheal window,

then cannula is

inserted in the

tracheal lumen.

Promptly,

the cannula cuff

is inflate at the

appropriate

pressure level and

heat and moisture

exchanger is

positioned: only

then the

ventilation is

resumed by close

airway circuit

attachment.

Tracheal

cannula should be

considered

correctly

positioned until

$\mathrm{CO} 2$ value is

displayed,

avoiding

stethoscope

contamination by

thoracic

auscultation.

$6 . \quad$ Kligerman

04-Apr-20

$$
\text { et } \mathrm{al}^{8}
$$

special

issue can be delayed

30 days after.
PPE- N95

mask, face shield, gown, and gloves.
- Closed

circuit ventilation.

- Cuffed

tracheostomy

tubes should be

used to decrease

leaks in

the circuit.

Use of in-

line suction, even

for patients who

may not require

chronic closed-

circuit ventilation

may

also decrease risk
Patients not on a closed ventilation circuit should wear a surgical mask over their stoma if tolerated as this may decrease spread of droplets from leakage around the stoma and/or HME.

tube change should be postponed 
of aerosolization and droplets.

Nebulizer treatments should be avoided or used with caution as well to minimize risk of aerosolization. and

manipulation of the tracheostomy site should be minimized.

- all nonurgent clinic visits should be postponed and/or converted to telehealth visits when possible.

$\begin{array}{ll}7 . & \text { Kowalski } \\ \text { 31-Mar- } & \text { et al } \\ 20 & \text { SPECIA } \\ & \text { L ISSUE }\end{array}$

$\quad$ wearing PPE
such as N95 or
FFP2 mask
or PAPR, gown,
cap, eye protection,
and gloves to
decreasing
the risk of
aerosolization.

- stop

ventilation while the tracheostomy window is being performed, and only resume ventilation when the cuff of the tracheostomy tube has been inflated.

$\begin{array}{ll}\text { 8. } & \text { Vargas et } \\ \text { 31-Mar- } & \text { al }^{10} \\ \text { 20 } & \text { SPECIA } \\ & \text { LISSUE }\end{array}$

full

protective wearing including N95 respirator, gown, cap, eye protection, and gloves.

- To avoid the

aerosol, push

down the

endotracheal tube

beyond the site

chosen for the

tracheal stoma at

the beginning of

the procedure.

The

endotracheal tube

should reach the

tracheal carina so

the cuff is surely

distal to the

tracheostomy site.

9. Xiao et

08-Apr-20

LETTER TO

THE

EDITOR

$$
\begin{aligned}
& \text { procedures } \\
& \text { should be } \\
& \text { performed under } \\
& \text { general } \\
& \text { anesthesia, with } \\
& \text { deprivation of } \\
& \text { spontaneous } \\
& \text { respiration and } \\
& \text { application of } \\
& \text { muscle relaxants } \\
& \text { regardless of } \\
& \text { whether patients } \\
& \text { had spontaneous } \\
& \text { breathing or not, } \\
& \text { to restrain the } \\
& \text { cough reflex } \\
& \text { caused by } \\
& \text { tracheal } \\
& \text { stimulation. }
\end{aligned}
$$




\begin{tabular}{|c|c|c|c|c|c|}
\hline & & & & 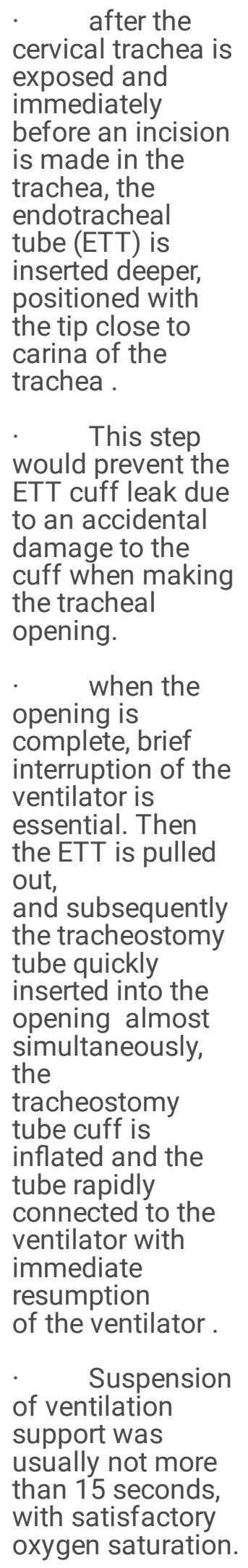 & \\
\hline $\begin{array}{l}10 . \\
\text { 08-Apr-20 }\end{array}$ & $\begin{array}{l}\text { Miles DDS } \\
\text { et al }^{12} \\
\text { S P E C IA } \\
\text { L I S S UE }\end{array}$ & $\begin{array}{l}\quad 21 \text { days } \\
\text { after the onset of } \\
\text { symptoms if } \\
\text { feasible. } \\
\text { Tracheostomy } \\
\text { should not be }\end{array}$ & $\begin{array}{l}\quad \text { waterproof } \\
\text { cap, goggles with } \\
\text { an antimist screen, } \\
\text { impermeable } \\
\text { operating room } \\
\text { surgeon's gown } \\
\text { and gloves and a } \\
\text { transparent }\end{array}$ & $\begin{array}{l}\quad \text { paralysis to } \\
\text { prevent } \\
\text { coughing. } \\
\text { glycopyrrolate to } \\
\text { reduce secretions. }\end{array}$ & $\begin{array}{l}\text {. Securing } \\
\text { circuits properly } \\
\text { and avoiding } \\
\text { unnecessary } \\
\text { humidification } \\
\text { systems may } \\
\text { reduce the risk } \\
\text { of unexpected }\end{array}$ \\
\hline
\end{tabular}

Page 10/23 
delayed

regardless of

SARS-CoV-2

status in lifesaving situations

or in situations

in which the

tracheostomy

would

significantly

improve the

prognosis of the

patient.

Ideally, the

procedure should

be performed at

bedside in the

intensive

care unit in a

negative pressure

room or using a

portable

high efficiency

particulate air

(HEPA) filtration

system to

avoid patient

transportation

and

contamination of

other

areas in the

medical center.

If it is

necessary to

perform

the procedure in

the operating

room (OR), a

specific OR

cluster should be

designated to

avoid

contamination of

additional OR

resources for

noninfected

patients. plastic facial shield

worn outside the

goggles and

N95.

The

minimum number

of health care

workers required to

perform

the procedure

should be present

to prevent

unnecessary

exposures.

Consideration for

power air-purifying

respirator (PAPR)

systems

for personnel

performing

tracheostomy

should be

entertained. preoxygenation

and cessation of

ventilation during

the tracheostomy

procedure.

- utilization

of closed

suctioning

systems.

\section{- $\quad$ avoiding}

monopolar

electrocautery, or

harmonic

technology, and

using cold

instrumentation

when feasible.

- $\quad$ minimizing

suctioning during

the procedure.

ensuring the

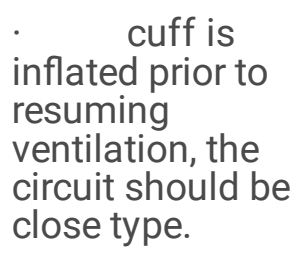

cuff is

resuming

ventilation, the

close type. circuit

disconnection

and

aerosolization

leading to

exposure.

The

circuit should

remain closed

as much as

possible, and

closed-line

suctioning

should be used.

moister

Heat

exchangers with

viral filters and

HEPA filtration

should

be used when

possible.

Tracheostomy

tube changes

should be

avoided and

should only be

performed in

cases of cuff

failure or

emergent

situations.

\begin{tabular}{|c|c|c|}
\hline \multirow{2}{*}{$\begin{array}{l}11 . \\
\text { 09-Apr-20 }\end{array}$} & $\begin{array}{l}\text { David et } \\
\text { al }^{13}\end{array}$ & $\begin{array}{l}21 \text { day } \\
\text { postintubation. }\end{array}$ \\
\hline & $\begin{array}{l}\text { SPECIA } \\
\text { LISSUE }\end{array}$ & $\begin{array}{l}\text { Ventilator } \\
\text { parameters to } \\
\text { qualify for safe } \\
\text { tracheostomy } \\
\text { placement } \\
\text { include positive } \\
\text { endexpiratory } \\
\text { pressure (PEEP) < } \\
12 \text { and fraction } \\
\text { of inspired }\end{array}$ \\
\hline
\end{tabular}

$\quad$ N95 mask or
PAPR, head
covering, eye
protection, gown,
and two pairs of
gloves.

$\quad$ Limit
number of
providers in the
room during the
procedure.
Use of
paralysis to
prevent coughing.
holding
ventilation when
the ETT cuff is
deflated and

Use of

closed, inline suctioning.

$\quad \quad$ Closed
circuit with
HEPA filter if
on mechanical
ventilatory
support.

when off 
oxygen $(\mathrm{FiO} 2)<$

0.60 .

- ICU

preferred or

negative

pressure room. when the trachea

is opened.

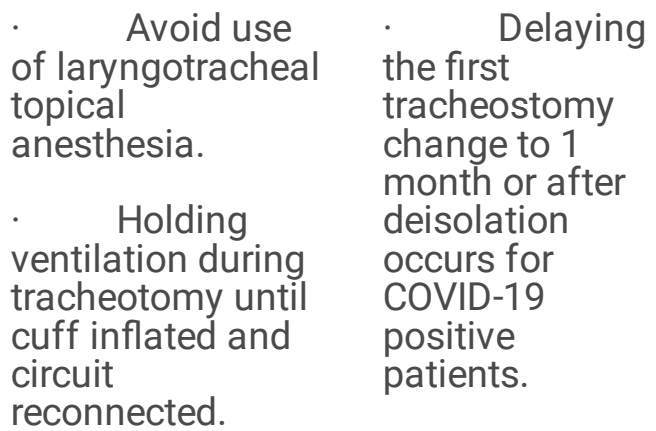

ventilatory

support.

the first

tracheostomy

month or after

deisolation

COVID-19

positive

reconnected.

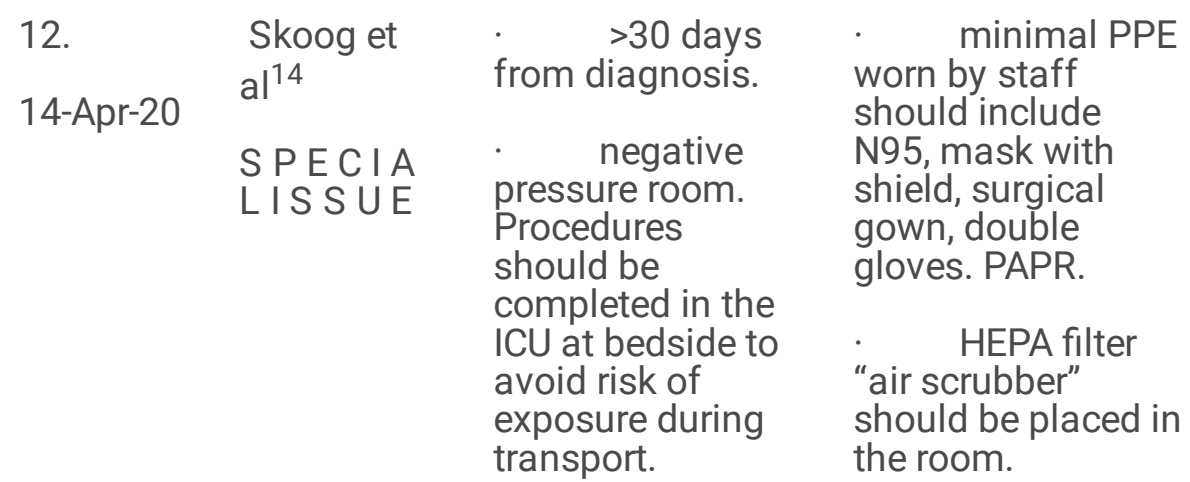

\begin{tabular}{|c|c|}
\hline \multirow{7}{*}{$\begin{array}{l}\text { Patients } \\
\text { were completely } \\
\text { paralyzed to } \\
\text { minimize air } \\
\text { movement } \\
\text { and coughing and } \\
\text { thus viral } \\
\text { dissemination via } \\
\text { aerosolization. }\end{array}$} & \\
\hline & suction system \\
\hline & with viral filter. \\
\hline & Keep cuff \\
\hline & inflated. \\
\hline & Delay \\
\hline & $\begin{array}{l}\text { first } \\
\text { tracheotomy }\end{array}$ \\
\hline $\begin{array}{l}\text { Just prior } \\
\text { airway }\end{array}$ & $\begin{array}{l}\text { tube change to } \\
3-4 \text { weeks, if }\end{array}$ \\
\hline try, the patients & possible avoid \\
\hline ygenated, & tracheotomy \\
\hline $\begin{array}{l}\text { Id, and the cuff } \\
\text { the }\end{array}$ & $\begin{array}{l}\text { after COVID has } \\
\text { passed. }\end{array}$ \\
\hline
\end{tabular}

endotracheal tube was dropped to minimize air movement over the respiratory mucosa.

While the patient was apneic, the tracheotomy incision was performed.
Open suctioning of the trachea was avoided.

Instead, a closed suctioning system with a viral filter was used.
ventilation only with cuff inflation. avoiding suctioning once the trachea is incised due to the risk of


aerosolization of

high viral load

secretions.

- $\quad$ minimizing

cautery due to

concerns of

aerosolization of

viral particles in

the smoke plume.

\begin{tabular}{|c|c|c|c|}
\hline 13. & Broderick & $\begin{array}{l}\text { "Covid dedicated } \\
\text { "Cove }\end{array}$ & $\begin{array}{l}\text { PPE- FFP3 } \\
\text { face mask, surgical }\end{array}$ \\
\hline $16-$ & & $\begin{array}{l}\text { Theatre", } \\
\text { operates under } \\
\text { negative }\end{array}$ & $\begin{array}{l}\text { hood, goggles } \\
\text { or visor and double } \\
\text { gloves. }\end{array}$ \\
\hline
\end{tabular}

pressure.

Reverse laminar

flow in the

perimeter around

the operating

table is estimated

to exchange $90 \%$

of air (removing

the generated

aerosol) in 6

minutes.

\section{- consider deep suctioning of the chest and oral cavity using the closed suctioning circuit prior to transfer to minimises the amount of secretions at the time of opening the trachea.

$\quad$ Security
staff has to close
the corridor
temporarily during
transfers, and the
anaesthetic team
needs to put on
PPE prior to
entering ICU.

The patient is transferred along the back corridor of the

theatres and not through the main theatre entrance.

viral filter should remain on the endotracheal tube.
The patient should be fully paralysed.

A closed suctioning is used.
- suction the

ET tube again, including

subglottic port .

- confirm

adequate muscle

relaxation.
keep a
closed circuit until
the tracheostomy
tube is inserted in
the trachea.

\section{Prior to tracheal window, stop the ventilator and deflate the balloon/cuff. Afterwards, the surgeon makes the window in the trachea. Minimal suctioning is used.
- Once the window is achieved the ET tube is advanced further (past the window) and the balloon/cuff is re-inflated (over- inflated),thus establishing a closed circuit.
- $\quad$ At this stage the patient is ventilated and the tracheal window lies above the level of the ET cuff allowing ample time for the surgeon to 
check

haemostasis and insert a rescuesuture.

The

ventilator is then stopped again, the cuff is deflated and the ET tube is withdrawn slowly to allow the insertion of the tracheostomy and inner tube.

The tracheostomy cuff is

inflated and the circuit is connected. The capnography $\mathrm{CO} 2$ trace is confirmed. The ET tube is simultaneously clamped while the tracheostomy is being placed.

Schultza et al $^{16}$

consesus

$\quad$ limitation of
the number of
caregivers present
in the operating
room.

full face shield/visor or airtight protective glasses. - FFP2 (N95) or FFP3 mask; - headlight covered by a head cap; -an impermeable protective apron or an overcoat that must be worn under the surgical gown as it is not sterile.

an apron or a gown, head protection with a hood cap rather than with a simple cap in order to better prevent any skin exposure,

\begin{tabular}{|c|c|}
\hline \\
\hline \\
\hline \multicolumn{2}{|c|}{$\begin{array}{ll}\text { the use of } & \text { hand scrub } \\
\text { electrocoagulation } & \text { and/or friction }\end{array}$} \\
\hline \multirow{3}{*}{\multicolumn{2}{|c|}{$\begin{array}{l}\text { which can } \\
\text { generate } \\
\text { aerosolization of } \\
\text { the virus when the } \\
\text { trachea is open; } \\
\text { - when possible, }\end{array}$}} \\
\hline & \\
\hline & \\
\hline \multirow{2}{*}{\multicolumn{2}{|c|}{$\begin{array}{l}\text { use a sterile } \\
\text { transparent }\end{array}$}} \\
\hline & tracheostomy \\
\hline \multicolumn{2}{|l|}{$\begin{array}{l}\text { interface between } \\
\text { the patient and } \\
\text { the surgeon, in }\end{array}$} \\
\hline \multirow{6}{*}{$\begin{array}{l}\text { the surgeon, in } \\
\text { order to limit the } \\
\text { risk of } \\
\text { contamination; } \\
\text { - if possible: carry } \\
\text { out a drug } \\
\text { assisted } \\
\text { neuromuscular } \\
\text { block to reduce } \\
\text { any risk of } \\
\text { coughing when } \\
\text { opening the } \\
\text { trachea; } \\
\text { - stop ventilation } \\
\text { just before the } \\
\text { trachea is incised; } \\
\text { Tracheostomy } \\
\text { under local } \\
\text { anesthesia is not } \\
\text { recommended. } \\
\text { However, if it is }\end{array}$} & spraying of $5 \%$ \\
\hline & $\begin{array}{l}\text { lidocaine into } \\
\text { the }\end{array}$ \\
\hline \\
\hline & \\
\hline & a few minutes \\
\hline \\
\hline \\
\hline \\
\hline & ventilated on \\
\hline \multicolumn{2}{|l|}{$\begin{array}{l}\text { - stop ventilation } \\
\text { just before the }\end{array}$} \\
\hline \multirow{2}{*}{\multicolumn{2}{|c|}{$\begin{array}{l}\text { trachea is incised; } \\
\text { Tracheostomy } \\
\text { under local }\end{array}$}} \\
\hline & \\
\hline & \\
\hline \\
\hline \\
\hline
\end{tabular}




necessary, it is
recommended to
inject 5 cc of
Lidocaine $5 \%$
intratracheally
through the
tracheal wall,
before the incision
of the trachea is
performed in order
to reduce the
cough reflex.

cough reflex. block to reduce any risk of coughing during the change of the cannula. All disposable material that has been in contact with the cannula or trachea (filters, suction probes) during the posttracheostomy care must be eliminated through the infectious waste circuit.

It is possible to use a room without air treatment provided that. the bedroom door is kept closed;

the patient's room is regularly ventilated; the air pressure in the room is maintained at zero.

the cannula should ideally be connected to an HME filter and covered by a surgical mask.

\begin{tabular}{|c|c|c|c|}
\hline $\begin{array}{l}14 . \\
\text { April 6, } \\
2020\end{array}$ & $\begin{array}{l}\text { Foster et } \\
\text { al }^{17} \\
\text { novel } \\
\text { approach }\end{array}$ & $\begin{array}{l}\quad \text { negative } \\
\text { pressure } \\
\text { operating room. }\end{array}$ & $\begin{array}{l}\quad \quad \text { PPE-boot } \\
\text { covers, sterile } \\
\text { gown, gloves, } \\
\text { surgical mask, } \\
\text { powered air- } \\
\text { purifying } \\
\text { respirators(PAPRs) }\end{array}$ \\
\hline
\end{tabular}

The Ecolab

Scope Pillow

Warmer Drape is a clear plastic material that is stretched over the retractor arms, forming a barrier between the operative field and the surgeon, while still allowing for good visualization of the operative field. 
The drape is then
secured with snaps
to the self retaining
retractor to
maintain the
tightness of the
drape; this will
improve visibility.
Buffalo Filter
smoke evacuator
tubing is
connected to 2
heat moisture
exchange (HME)
filters and placed
under the drape to
provide further air
filtration
The operator and
assistant will
proceed with
hands underneath
the drape.

$\begin{array}{lll}15 . & \text { Youn et } & \text { at bedside } \\ \text { Jul 2, } & \text { al }{ }^{18} & \text { in a negatively } \\ 2020 & \text { case report } & \begin{array}{l}\text { pressured ICU } \\ \text { room to minimize } \\ \text { the risks of } \\ \text { transmission } \\ \text { during transfer } \\ \text { and worsening of } \\ \text { the patient's } \\ \end{array} \\ & & \\ & & \\ & & \end{array}$

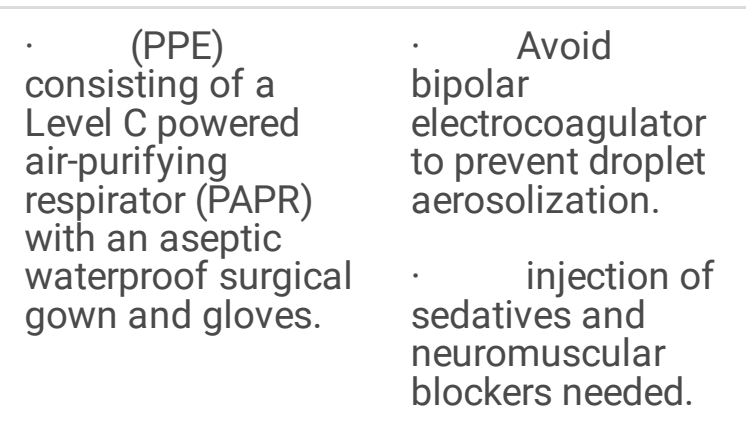

Prior to opening of the second tracheal ring, the $\mathrm{FiO} 2$ was lowered to 0.4 and the balloon was temporarily overinflated.

The balloon was below the level of the tracheal opening.

No droplets
escaped the
opening due to the
repositioned and
overinflated
balloon. The ET
tube was
withdrawn until
the tip of the tube
reached above the
tracheal opening.
$\quad$ During
withdrawal, to
prevent the spread
of droplets,




\begin{tabular}{l} 
pausing the \\
ventilator was \\
considered before \\
balloon deflation. \\
Immediately after \\
ET tube tip \\
repositioning, a \\
hole was made on \\
a transparent film \\
dressing with \\
scissors and a \\
tracheostomy \\
tube was \\
immediately \\
inserted. \\
\multicolumn{1}{c}{ After a } \\
quick check of \\
tracheostomy \\
tube patency with \\
a rubber catheter, \\
the ventilator was \\
connected, the \\
tidal volume was \\
checked, and the \\
existing ET tube \\
was removed.
\end{tabular}

\section{Discussion}

General Recommendations for Tracheostomy in COVID-19 Patients based on systemic analysis of included articles is developed as under:

TIMING OF TRACHEOSTOMY: There is no evidence as to the optimal timing of tracheostomy, when considering the current literature with respect to the disease process, the best use of healthcare resources, and staff safety waiting for 14 - 30 days will be beneficial. The evidence thus far in terms of viral load risk would suggest that delaying tracheostomy to at least 14 days postintubation would represent the safest possible balance. Given the natural disease course, this would likely represent at least 3 weeks since the onset of symptoms. Timing of procedure preferably applied between ventilator days 14-21 when viral load is expected to be decreasing and 2130 days after onset of symptoms.

PLACE OF PROCEDURE: The ideal location for performing a tracheostomy on a COVID-19 positive patient is isolated room with lower pressure than the corridor. If unavailable, use a room with closed doors-windows and no laminar flow or Operating room or ICU room with negative pressure or using a portable high efficiency particulate air (HEPA) filtration system at bedside ICU setup. This setting would be ideal but not always feasible due to their limited availability and resource implications in a pandemic. 
PREPARATION AND SAFETY: Personal protective equipment - PPE should include: Fitted respiratory mask [N95 OR PAAR OR PFF3], surgical cap, impermeable sterile gown, shoe covers, goggles, and full-face shields, sterile double gloves and additional surgical mask (in front of the N95 or PFF3) can be used. Minimize number of people in the room to 3 ( 2 procedural staff-ENT surgeon and anaesthetic). Use a conventional tracheostomy tube avoiding the fenestrated models. HEPA filter "air scrubber" should be placed in the room. Consider deep suctioning of the chest and oral cavity using the closed suctioning circuit prior to transfer to minimises the amount of secretions at the time of opening the trachea. Security staff has to close the corridor temporarily during transfers and the anaesthetic team needs to put on PPE prior to entering ICU. The patient is transferred along the back corridor of the theatres and not through the main theatre entrance. viral filter should remain on the endotracheal tube.

\section{OPERATIVE STEPS/TECHNIQUE MODIFICATION:}

- Avoid electrocautery - risk of smoke formation and viral transmission via aerosol.

- Pre oxygenation with PEEP then stop ventilation and turn off flows.

- Allow time for passive expiration with open APL valve.

- To avoid the aerosol consider clamping of ET then deflate cuff and push down the endotracheal tube beyond the site chosen for the tracheal stoma at the beginning of the procedure.

- The endotracheal tube should reach the tracheal carina so the cuff is surely distal to the tracheostomy site. This step would prevent the ET cuff leak due to an accidental damage to the cuff when making the tracheal opening.

- Create the tracheal window, minding the cuff, deflate it and pull the tube until the tip is proximal to the tracheal window.

- when the opening is complete, brief interruption of the ventilator is essential. Then the ET is pulled out, and subsequently the tracheostomy tube quickly inserted into the opening almost simultaneously, the tracheostomy tube cuff is inflated and the tube rapidly connected to the ventilator with immediate resumption of the ventilator.

- At this stage the patient is ventilated and the tracheal window lies above the level of the ET cuff allowing ample time for the surgeon to check haemostasis and insert a rescue-suture.

- Suspension of ventilation support was usually not more than 15 seconds, with satisfactory oxygen saturation.

- No tracheal or wound suctioning of blood or secretions should be attempted if not needed, to avoid aerosol generation.

- insert cuffed, non-fenestrated tracheal tube only.

- confirm position with end tidal $\mathrm{CO} 2$ only to avoid contamination of stethoscope by auscultation.

- An HME type filter (Heat and moisture exchanger) must be placed on the tracheostomy tube to reduce the exposure of the virus, in case of disconnection of circuit.

- Nebulizer treatments should be avoided or used with caution as well to minimize risk of aerosolization. keep a closed circuit until the tracheostomy tube is inserted in the trachea. 
- Team involved in the procedure use a shower for body cleaning.

- Avoid humidified oxygen, use only HME filters.

- suctioning always in a closed circuit.

- cuff always inflated.

- Avoid dressing changes unless there are clear signs of infection.

- Avoid switching the cannula before 7 to 10 days, giving preference to a period of lower viral load.

- Follow same sequence of pause in ventilation with flows off before deflating cuff and inserting new tube with immediately re-inflation of cuff and reconnection of circuit.

- Use full PPE for exchanges.

- Deflate the cuff only with the flow off and inflate the cuff of the new cannula immediately after insertion.

- Next Subsequent planned tube change at least 30 days interval.

- Avoid changing the tracheostomy tube until the patient has a COVID-19 negative report.

- The cannula should be held during any passive movement of the patient to avoid air leakage from the stoma.

- Patients not on a closed ventilation circuit should wear a surgical mask over their stoma if tolerated as this may decrease spread of droplets from leakage around the stoma and/or HME.

- Manipulation of the tracheostomy site should be minimized.

- all nonurgent clinic visits should be postponed and/or converted to telehealth visits when possible.

- Use Closed circuit with HEPA filter if on mechanical ventilatory support.

- Use HME when off ventilatory support.

- If the patient is ventilated on the tracheostomy cannula, the anesthesiologist can be asked to sedate the patient and perform a neuromuscular block to reduce any risk of coughing during the change of the cannula.

- All disposable material that has been in contact with the cannula or trachea (filters, suction probes) during the post-tracheostomy

care must be eliminated through the infectious waste circuit.

- It is possible to use a room provided that, the patient's room door is kept closed; the patient's room is regularly ventilated; the air pressure in the room is maintained at near zero,

the cannula should ideally be connected to an HME filter and covered by a surgical mask.

- Use of cannulas without fenestrations until the COVID exam is negative.

The focus of early post-procedural care is to ensure minimisation of aerosol generation risk to healthcare workers and other patients until any risk has passed. Early measures include keeping the cuff inflated, use of in-line suction, and avoidance of humidified oxygen if possible. Cuff deflation, changing of tracheostomy tube and progress on a decannulation protocol should be deferred until the patient is COVID19 negative where possible. We suggest reducing the frequency of changing an inner cannula (if used) and cuff pressure checks; these decisions should be made on an individual basis and reviewed daily. We recommend commencing care after tracheostomy with a simple heat and moisture exchange filter to provide humidification; the requirement for heated, water-based humidification or adjuncts, such as saline or hypertonic saline nebulisers, should be made on an individual basis and reviewed daily. We suggest that facemasks and tracheostomy shields be used by patients undergoing trials of tracheostomy cuff deflation to mitigate risks of aerosols 
ANESTHETIC CONSIDERATIONS: Deep neuromuscular blockade should be instituted. Avoid circuit disconnection as much as possible.

\section{Conclusion}

Our recommendations on the use of tracheostomy during the COVID-19 pandemic are presented in above mentioned panel. A defining feature of this pandemic is its pervasive and variable character. Increases in the number of patients with COVID-19 who are critically ill can swiftly overwhelm hospitals, particularly because many require extended periods of ventilator support, and many will require tracheostomy to facilitate recovery. Because tracheostomy is at the intersection of health-care worker safety, resource allocation, and patient-centred care, sound guidance is crucial. Many questions remain unanswered, and prospective data are needed to answer pressing questions around tracheostomy in the setting of the COVID-19 pandemic. Data on infectivity and persistence of viral RNA in patients who are critically ill are sparse, particularly at timepoints beyond 20 days after symptom onset, when tracheostomy is typically considered. The predictive value of peak viral load and antibody response for gauging infectivity and transmission risks associated with different strategies for tracheostomy insertion require further study. Tracheostomies in COVID-19 patients present themselves as extremely high-risk procedures for all members of the procedural team. Systematic meticulous planning of each procedural step is warranted along with strict adherence to local/ institutional protocols to mitigate risk to procedural members. These proposals provide a robust framework on which to base delivery of tracheostomy services for critical care units during the COVID-19 pandemic, this can prove an invaluable resource .At present, there is no high-level evidence beyond case series upon which to make definitive recommendations, but we have based our proposed guidelines upon consensus from the currently available literature to form a pragmatic and safe approach. There is no doubt that as more rapidly emerging higher-level evidence becomes available, our recommendations will be refined and improved. The decision to perform tracheostomy in these patients requires careful consideration, planning and regular scrutiny if it is going to be of net benefit to patients and critical care services in terms of optimising healthcare resource utilisation, ensuring patient and staff safety and providing optimal long-term outcomes. Urgent planning, training and collaborative data collection will be vital, and ENT surgeons have the potential to offer a valuable role in supporting critical care teams with this service at a very challenging time.

\section{Abbreviations}

PAPR: powered air purifying respirators, PPE-Personal protective equipment, HME- Heat and Moisture exchanger, HEPA- high efficiency particulate air. PEEP - positive end expiratory pressure. APL-adjustable pressure limiting valve, ET- endotracheal tube.

\section{Declarations}

\section{Conflict of Interest:}

There is no conflict of interest among authors.

\section{References}


[1] Zhu N, Zhang D, Wang W, et al. A novel coronavirus from patients with pneumonia in China, 2019. N Engl J Med 2020. https://doi.org/10.1056/NEJMoa2001017.

[2] World Health Organization (WHO). Coronavirus disease (COVID-19) Pandemic. Weekly update on 20 september at $10 \mathrm{am}$.

[3] Menegozzo CA, Arap SS, Mariani AW, Minamoto H, Imamura R, Bento RF, PÊGO-FERNANDES PA, Kowalski LP, UTIYAMA E. Standardization of elective tracheostomies at the Central Institute of the Hospital das Clínicas in São Paulo during the COVID-19 pandemic. Revista do Colégio Brasileiro de Cirurgiões. 2020;47.

[4] Jacob T, Walker A, Mantelakis A, Gibbins N, Keane O. A framework for open tracheostomy in COVID-19 patients. Clinical Otolaryngology. 2020 Apr 13.

[5] Lima DS, Junior MF, Vieira-Jr HM, de Campos T, Di Saverio S. Alternatives for establishing a surgical airway during the COVID-19 pandemic.

[6] Botti C, Lusetti F, Castellucci A, Costantini M, Ghidini A. Safe tracheotomy for patients with COVID-19. American Journal of Otolaryngology. 2020 May 7:102533.

[7] Pichi B, Mazzola F, Bonsembiante A, Petruzzi G, Zocchi J, Moretto S, De Virgilio A, Pellini R. CORONA-steps for tracheotomy in COVID-19 patients: A staff-safe method for airway management. Oral oncology. 2020 Jun;105:104682.

[8] Kligerman MP, Vukkadala N, Tsang RK, Sunwoo JB, Holsinger FC, Chan JY, Damrose EJ, Kearney A, Starmer HM. Managing head and neck cancer patients with tracheostomy or laryngectomy during the COVID-19 pandemic. Head \& Neck. 2020 Jun;42(6):1209.

[9] Kowalski LP, Sanabria A, Ridge JA, Ng WT, de Bree R, Rinaldo A, Takes RP, Mäkitie AA, Carvalho AL, Bradford CR, Paleri V. COVID-19 pandemic: effects and evidence-based recommendations for otolaryngology and head and neck surgery practice. Head \& neck. 2020 Jun;42(6):1259-67.

[10] Vargas M, Servillo G. Improving staff safety during tracheostomy in COVID-19 patients. Head \& neck. 2020 Jun;42(6):1278-9.

[11] Xiao H, Zhong Y, Zhang X, Cai F, Varvares MA. How to avoid nosocomial spread during tracheostomy for COVID-19 patients. Head \& Neck. 2020 Jun;42(6):1280-1.

[12] Miles BA, Schiff B, Ganly I, Ow T, Cohen E, Genden E, Culliney B, Mehrotra B, Savona S, Wong RJ, Haigentz M. Tracheostomy during SARS-CoV-2 pandemic: Recommendations from the New York Head and Neck Society. Head \& neck. 2020 Jun;42(6):1282-90.

[13] David AP, Russell MD, El-Sayed IH, Russell MS. Tracheostomy guidelines developed at a large academic medical center during the COVID-19 pandemic. Head \& neck. 2020 Jun;42(6):1291-6.

[14] Skoog H, Withrow K, Jeyarajan H, Greene B, Batra H, Cox D, Pierce A, Grayson JW, Carroll WR. Tracheotomy in the SARS-CoV-2 pandemic. Head \& neck. 2020 Apr 28. 
[15] Damian B, Panayiotis K, Kevin S, Alistair S, Chetan K, Leandros V. Surgical tracheostomies in Covid-19 patients: Important considerations and the "5Ts" of safety. British Journal of Oral and Maxillofacial Surgery. 2020 Apr 16.

[16] Schultz P, Morvan JB, Fakhry N, Morinière S, Vergez S, Lacroix C, Bartier S, Barry B, Babin E, Couloigner V, Atallah I. French consensus regarding precautions during tracheostomy and post-tracheostomy care in the context of COVID-19 pandemic. European annals of otorhinolaryngology, head and neck diseases. 2020 May 1;137(3):1679.

[17] Foster P, Cheung T, Craft P, Baran K, Kryskow M, Knowles R, Toia A, Galvez C, Bowling A, DiSiena M. Novel approach to reduce transmission of COVID-19 during tracheostomy. Journal of the American College of Surgeons. 2020 Jun 1;230(6):1102-4.

[18] Youn SH, Baek SY, Yoon J, Hong SS, Kim Y. A Case Report of Tracheostomy for a Patient with COVID-19: How to Minimize Medical Staff and Patient Risks. Journal of Korean medical science. 2020 Jul 20;35(28)

\section{Figures}




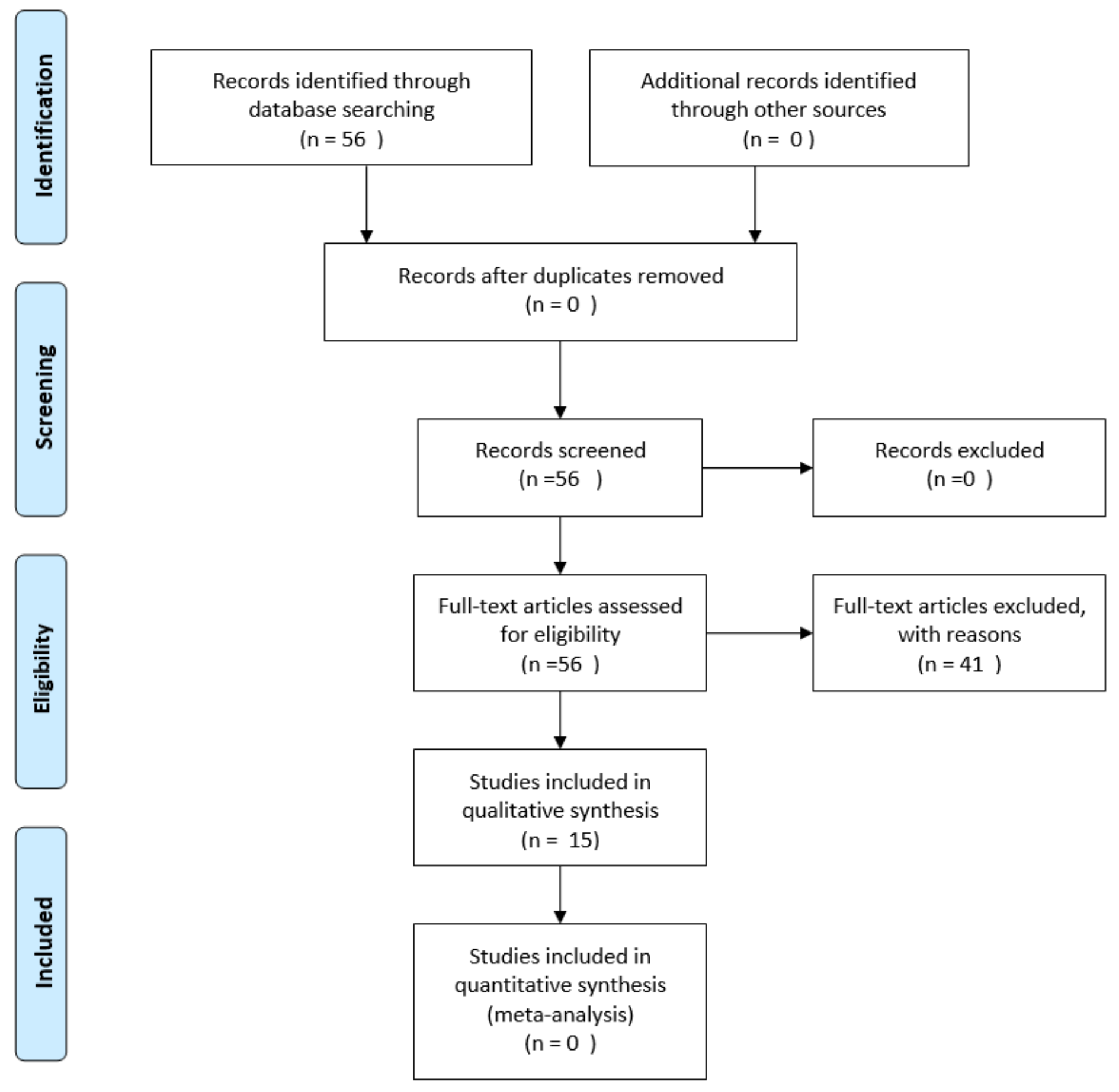

Figure 1

From: Moher D, Liberati A, Tetzlaff J, Altman DG, The PRISMA Group (2009). Preferred Reporting Items for Systematic Reviews and Meta-Analyses: The PRISMA Statement. PLoS Med 6(7): e1000097. doi:10.1371/journal.pmed1000097 For more information, visit www.prisma-statement.org. 